ELORE (ISSN 1456-3010), vol. $17-1 / 2010$.

Julkaisija: Suomen Kansantietouden Tutkijain Seura ry.

[http://www.elore.fi/arkisto/1_10/pk_aarnipuu_1_10.pdf]

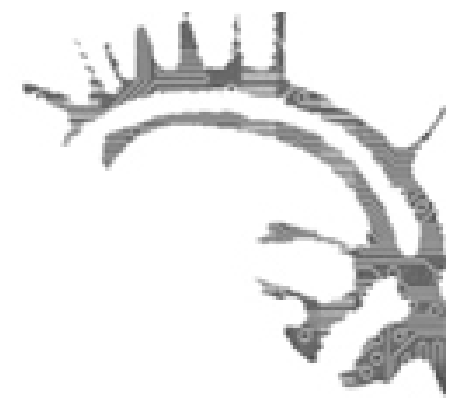

\title{
PÄÄKIRJOITUS
}

\section{KESKELLÄ VERKKOA}

\section{Petja Aarnipuu}

Työtön vaan ei toimeton, viraton mutta täystyöllistetty, mikä se on? No se on työelämänkuvaus, joka on yhä tutumpi ja tavallisempi akateemisille tieto- ja tiedeammattilaisille. Työtä, työtä, työtä tehdään, mutta usein joko ilman varsinaista työpaikkaa tai toimessa ilman virkaa. Esimerkiksi Helsingin yliopistossa virattomuus on yltänyt professoritasolle, kirjaimellisesti. Vuodenvaihteessa tapahtuneen uudistuksen jälkeen virat ovat jääneet historiaan (työsuhteet toki jatkuvat). Akateemisen työn maailma muuttuu, nimekkeet tulevat ja menevät, liike on ikuista.

Eloressakin liikutaan. Outi Fingerroos on luovuttanut vetovastuun minulle, mutta hän on kyllä luvannut monien muiden töidensä ja vastuidensa ohella jatkaa lehdessä vapaana toimittajana. Omasta ja toimituksen puolesta esitän vielä kerran suuret kiitokset Outille! Tämän lehden sivuilta saamme lukea muun muassa, mitä Outi teki ja näki Etiopiassa. Toimettomana hän ei ainakaan ollut.

Eloren vastaavat päätoimittajat ovat tähän saakka olleet hyvin kiinteässä suhteessa johonkin maamme yliopistoista. Minullekin yliopisto on vanha ystävä. Kävelin sen ovesta sisään ensimmäistä kertaa syksyllä 1990, teologian ylioppilaana. Keväällä 2008 kävelin sen ovesta ulos folkloristiikasta väitelleenä filosofian tohtorina. Sittemmin suhdettamme on sävyttänyt toverillinen yhteistyö ja avunanto. Virkaa tai edes tointa minulla ei ole, ei yliopistolla eikä muuallakaan. Liikkuvuuden keskelle, pysyväksi kiinnekohdaksi ostin perheineni 100-vuotiaan talon Hämeestä. Se on samalla eläkevakuus, jonka arvoon voimme omien kättemme työllä vaikuttaa. Kätten työtä olen sittemmin kovasti harjoitellut. Osaan nyt rakentaa seinän ja olen siitä yhtä ylpeä kuin aikanaan proseminaarityöstäni. Päivittäiset työkaluni ovat vaihdelleet tekstinkäsittelyohjelmasta lapioon ja excelistä iskevään ruuvinvääntimeen. ('Yliopistomies", olen huomannut, saa onneksi paljon anteeksi remonttityömaalla: juuri mitään ei odoteta ja bonuspisteitä tulee likaisista haalareista.) 
Nykyinen työnkuvani on se lukemattomille kollegoilleni ja ikätovereilleni tuikituttu reunaton palapeli, jonka osasina on sekä satunnaisia yliopistotöitä että erilaisia kirjoitusurakoita irrallaan yliopistosta. Työ ja tulo kohtaavat tässä mallissa harvakseltaan. Minulla kuvaan kuuluu myös Elore, jonka päätoimittajuutta pidänkin yhtenä tärkeimmistä töistäni. Ainoastaan sähköisten kommunikaatiojärjestelmien olemassaolo ja toimivuus tekevät mahdolliseksi tällaisen työelämän, jossa pirstaleisuuden ja epävarmuuden vastapainona on hieman kulahtanut hirsitalo taivaanrannassa. Laajakaistan ansiosta hämäläinen syrjäkylä voi näin olla myös minulle Eloren vastaavana päätoimittajana yhtä lailla näköalapaikka perinteen- ja kulttuurintutkimukseen kuin se Helsingin itäinen kantakaupunkikin, josta tänne muutin.

Elore ilmestyy ja elää verkossa, jonka solmukohtina ovat ihmiset tietokoneineen. Eloren vuodenkierrossa tehtäväni on - vastuun kantamisen lisäksi - toimitustyön koordinoiminen ja sen tulosten yhteenkokoaminen. Lehden toimittajat ovat tiiviissä yhteydessä maailmaan ja perinteentutkimukseen muun muassa helsinkiläisestä, joensuulaisesta, jyväskyläläisestä ja kahdesta turkulaisesta yliopistosta käsin. Tämän uuden vuosikymmenen ensimmäinen, aistimaailmaan sijoittuvan Eloren teemanumeron päätoimittajana on Eerika Koskinen-Koivisto. Hän puolestaan on tehnyt päätoimittajan työtään Yhdysvalloissa, Columbuksessa, ollessaan Ohio State Universityn Fulbright-stipendiaattina. Verkkolehden toimitustyön kannalta on aivan sama, olemmeko Helsingissä ja Jyväskylässä vai Hattulassa ja Columbuksessa. Yhteistyö on ollut sujuvaa ja sukkelaa!

Eloren toimitus kokoontuu joukolla keskustelemaan lehden kulloinkin seuraavaksi tehtävästä numerosta ja laajemmista linjoista kahdesti vuodessa, voileipätarjoilun voimin. Ideoista, uutisista ja tapahtumisista ei ole ollut pulaa. Toimituskunnalla on vahva ja valtaosin jaettu näkemys siitä, millaista lehteä haluamme tehdä. Suunnittelukokouksen jälkeen hajaannumme kukin omiin maankolkkiimme. Artikkelitoimitus, ajankohtaistoimitus ja kirja-arviotoimitus ryhtyvät hommiin sen mukaan kuin on sovittu, kirjoittamaan omia juttujaan ja toimittamaan erilaisia tekstejä, joiden kirjoittajat puolestaan saattavat asua missä hyvänsä. Kirjoitus- ja toimitustyön tulokset saapuvat toimitusten vastaaville ja heiltä päätoimittajille yleensä asetettuun aikarajaan mennessä. Sitten viimeistellään, taitetaan, tarkistetaan, korjataan - ja lähetetään takaisin maailmalle. Hätäkös näin hyvin toimivaa systeemiä on pyörittää!

Filosofian tohtori Petja Aarnipuu on vapaa tutkija Hattulasta. 